\title{
RENAL CELL CARCINOMA
}

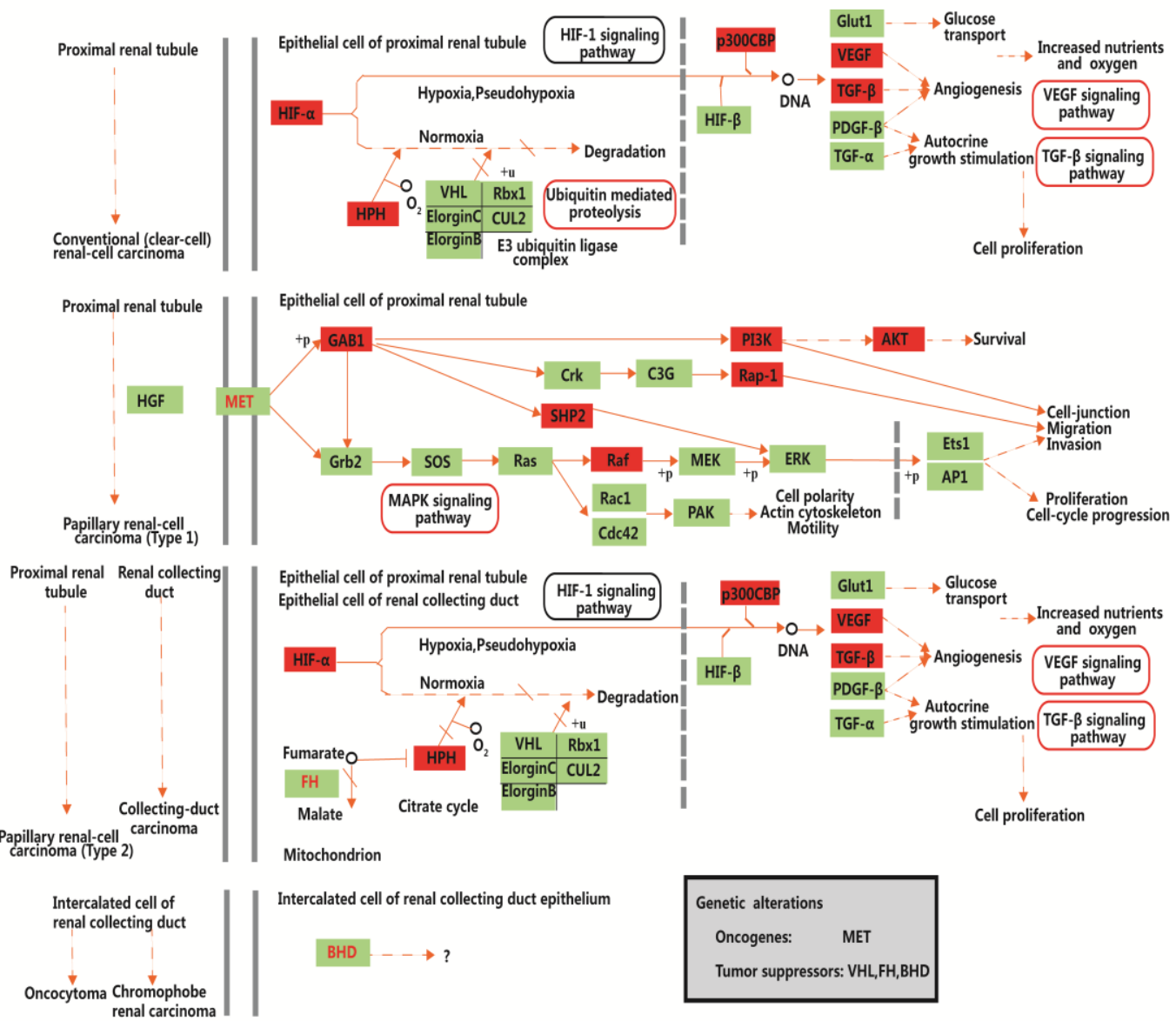

S5 Fig. Renal cell carcinoma pathway enriched by 15 putative target genes of upregulated miRNAs. Red boxes represent the target genes of miRNAs. 